\title{
STUDIES OF EVERYDAY LIFE IN CONTEMPORARY UKRAINIAN HISTORIOGRAPHY: FROM IMITATION TO FIRST RESULTS
}

\section{Lyakh S. R.}

\section{INTRODUCTION}

The studies of everyday life have been in the focus of Ukrainian historiography since late 90s. Moreover, there is a certain fashion to flirt with the terms such as "everyday life", "microhistory", "life strategies", "practices". However, the question is how these slogans correspond to the actual content of the new history studies.

It is quite natural, that the systemic turn in approaches to the reporting starts with a speculative comprehension of the papers of general epistemology. In Ukraine, the peak of formalized theoretical-methodological interest in the principles of the studies of everyday life and even its seeming propaganda falls on the period of 2006-2015. Still, such "theoretical" papers has a number of achievements, such as introducing comprehensive bibliography, outlining the ideas of Western colleagues on the prospects of enriching the arsenal of research tools of historians, developing the categorial apparatus of microhistory and studies of everyday life.

All authors who have proved to be the advocates of the new trend in history research invariably highlight the collective monographs series by the Institute of History of Ukraine of the NAS of Ukraine, published under the slogan "From the studies of everyday life in Ukraine"1. It is worth mentioning, that all of the volumes have lengthy introductions comprising historiographical essays with references to foreign authors and meticulous explanations what the story "should be". Moreover, in the succeeding sections dedicated to specific historical issues, the actual history of everyday life is interspersed with common sociological-positivist discourse.

The first achievements of Ukrainian historians in studies of everyday life and relevant outspoken proposals on the prospects of further dedicated

\footnotetext{
${ }^{1}$ Нариси повсякденного життя радянської України в добу непу (1921-1928рр.) / Відп. ред. С.В. Кульчицький. В 2 ч. Київ: Інститут історії України НАН України, 2009-2010; Українське радянське суспільство 30-х рр. ХХ ст.: нариси повсякденного життя / Відп. ред. С.В. Кульчицький. Київ: Інститут історії України НАН України, 2012; Повоєнна Україна: нариси соціальної історії (друга половина 1940-х - середина 1950-х рр.). У 2-х книгах, 3-х частинах / Відп. ред. В.М. Даниленко. - Київ: Інститут історії України НАН України, 2010; Повсякдення ранньомодерної України. Історичні студії в 2-х томах / Гол. ред. В. Смолій; Відп. ред. В. Горобець. - Київ: Інститут історії України, 2012-2013.
} 
historical studies received proper attention at a number of scientific-practical conferences ${ }^{2}$.

In general, the first decade of keen interest to the studies of everyday life was marked by the dominance of theoretical and organizational searches rather than practical results. The problem which remains significant is the need to overcome such quasi-microhistorical activities as imitation of the everyday life historical studies, sheer daily routine reporting, empirical routine, facts abuse. In this respect, it's worth quoting Paul Riceur's remark: philosophers should study the experience of historians and be in no hurry to teach them how to study history ${ }^{3}$. So, the time of hard work for "practicing historians" has come.

Recent publications have provided the necessary material to facilitate further studies, grounded not only on historiographical speculation, but also on dedicated examples of big-scale researches. This study is bound to help see the difference between traditional history reporting and the technology of everyday life studies, as well as to understand how the magic works, when the puzzle pieces fit together to make the picture of essence.

\section{Alternative look at the Hetmanate: historical presentation by Tatyana Tairova-Yakovleva ${ }^{4}$}

The famous researcher of the history of the Hetmanate of the XVII - the beginning of XVIII centuries, Tatiana Tairova-Yakovleva, reaffirms her talent as a historian in her new book. Defining her work as a "story", from the first page T. Tairova-Yakovleva focuses on a living person, rather than institutions or structures. The author invites the reader to make a "journey ... into the world of people...", but at the same raises the bar and notes that she's going to dwell upon cherished ideas of truth. Starting her book with the words like "everyday life" and "leisure", T. Tairova-Yakovleva tunes the reader onto a thoughtful conversation about the "values" of the Ukrainian elite, about the

\footnotetext{
2 Історія повсякденності: теорія та практика. Матеріали Всеукраїнської наукової конференції, Переяслав-Хмельницький, 14-15 травня 2010 р. Переяслав-Хмельницький, 2010; Історія радянської повсякденності: на перехресті джерел. Збірник матеріалів Всеукраїнського науково-теоретичного семінару, 14-15 травня 2015 р., м. Вінниця. Вінниця, 2015.

${ }^{3}$ Рікер, Поль. Історія та істина. Київ, 2001. С. 30: “A philosopher cannot teach a historian something here; always the opposite - the philosopher learns from the practice of applying some branch of science. Therefore, we must first listen to the historian when he reflects on the problems of his scientific profession ...". - This is about interpreting the problem of objectivity, so the advice to philosophers to more carefully consider the cognitive experience of professional historians is appropriate when it comes to ways of research and presentation of the past.

${ }^{4}$ Таїрова-Яковлева Т. Повсякдення, дозвілля і традиції козацької еліти Гетьманщини Київ: ТОВ «Видавництво КЛІО», 2017.
} 
"mindset of a free individual, who can manage their own destiny and rule their country". The components of mindset are referred to as "tradition of active participation in the life of a country", "awareness of self-importance and independence", "the chivalric nature of the cossack military service". The object of contemplation is defined as "a society, which believed in God, freedom and success" ". Therefore, before diving into the world of objects and traditions, the author outlines the general plan of her research and sets the semantic framework of her discourse.

However, the historian relies not on ideological premises, but on the objective world: "Go and see" (instead of "philosophize and teach").

In this book the historian's attention is shifted from the battlefields, urban settings, halls of power, councils, boards and committees to the periphery, to the private premises, to the guest rooms, cellars (where treasure boxes with precious coins are stored), to the cosy nooks of gardens and parks, to the realm of ideas, tastes, dreams and feelings.

The book is full of descriptions of "comfort and convenience", details of the world that surrounded the Ukrainian elite. There is the variety of fabrics, accessories, motifs and techniques of embroidery; colour palette; jewellery; collections of rich weapons; it causes a genuine sympathy, genuine wonder. Wells, ponds, gardens, parks, stables, forges, bakeries, glaciers, baths, barns all these objects appear as the natural environment of the collective hero of the book. Moldings, bas-reliefs, tiles, icons, mirrors, carpets, furniture, lamps, linen, curtains, porches, lamps are not collections and not artistic exercises of historian. This is a delineation of the living space of the elite of early modern Ukraine. This is an occasion to talk about how people welcomed guests, how they communicated, discussed important matters, sought and provided advice. Dishes, drinks, spices and sweets, all this "variety of food on the tables of the Ukrainian elite" is a conversation about the world of care, the testament to the power of life. Family coat-of-arms on a silver household and on portraits, receptions, gatherings, travels, a marching way of life are an occasion to talk about the mode of life and mentality of those same persons who in the previous monographs of Tairova-Yakovleva have appeared in the role of generals, officials, rebels, leaders, adventurers. The detailed list of musical instruments, analysis of musical tastes, descriptions of orchestras, descriptions of private libraries, chess games are evidence of the level of intelligence.

Household things in T. Tairova-Yakovleva's book are not simply listed and described. They live the lives of their owners. They are used in ceremonies, accompanying their hosts on journeys. They are taken with them in exile to Siberia, they are ordered, inherited, used for posing in ceremonial portraits.

\footnotetext{
${ }^{5}$ ibid. P. 3,8.
} 
Wherever possible, the author clarifies under what circumstances "certain" items were illuminated: dowry, confiscation of property from a disgraced sergeant, scenario of receiving an embassy, performing duties, resting. Typically, descriptions of things are provided along with the names of their owners. So, there are no "general" things. Things are the environment and the continuation of a person. Whatever the detail of things, there is always a living person at the centre of the story with her aspirations, worries, ambitions, tastes. It is not a museum. It is the world of people, the history of society.

Thoroughly listing the details of the architectural decoration of the homes of Ukrainian hetmans and petty officers, T. Tairova-Yakovleva certainly finds the human equivalent of things: in all this there is "a lot of naivety and heartfelt simplicity" ". She carefully examines the details of the portraits of the seventeenth century to "look at them clearly, better understand and imagine". In portraits, the heroes of her book appear "happy and contented with life"; they are "strong and hardy"7. The proficiency of the Latin by petty officers and hetmans, details of student life (debates, performances, poems, recitals, dialogues) give reason to say: "it was a society of educated people" ${ }^{8}$. In the details of the Ukrainian early-fashioned vertebrate tradition (culture), the historian sees the civilizational characteristics: "Unlike in Western European Baroque, where much attention was paid to death ... for the Ukrainian baroque, the main subjects were military glory, sacrifice, high impulse, victory of life over death"'.

After a generous presentation of all kinds of goods, attributes, things, family values, habits and customs, in the final section of her work, T. TairovaYakovleva comes to the integral characteristics: "it was a new elite, not yet tainted, restrained by laws and traditions..."; "one of the defining features of that society was modesty"; "Ukrainian society of the hetman era was striking with the combination of southern temperament, Baroque sophistication and sentimentality" ${ }^{\prime 10}$.

Testifying for property, disputes over the management of dowry, charity, founding monasteries, private correspondence, family disputes, private intrigues, which classical historiography mostly ignores as insignificant and insignificant, T. Tairova-Yakovleva uses them as an argument of historical weight. She describes in detail the facts of women's involvement in both family affairs and formal receptions and ceremonies, and notes such features of their social status as "freedom, economic independence and serious legal

\footnotetext{
${ }^{6}$ Ibid. P. 21.

${ }^{7}$ Ibid. P. $90-91$.

${ }^{8}$ Ibid. P. 10.

${ }^{9}$ Ibid. P. 131.

${ }^{10}$ Ibid. P. 113, 148, 150.
} 
rights", "dignified place in society"11. The author tells a series of "life stories" of bright and successful (but with dramatic biography) women of the Hetmanate region and is not afraid to hint at the role of passion in history "fatal women".

Ultimately, T. Tairova-Yakovleva rehabilitates the historical dignity of the Ukrainian elite of the period of the "Young Hetmanate", removes from the image of the Cossack officers the stratification of class contempt, outrageous criticism, which several generations of historians and history buffs have hung on to this social stratum. It is not through contractual articles of the Ukrainian hetmans with the tsarist, royal, sultan governments. It is not through power intrigues, schemes, coalitions. Her view is "simple", direct and immediate, naive in something (though the look of an experienced researcher cannot be truly naive, it is cunning naivety, not easy naivety).

In the array of things, in the atmosphere of traditions, rituals, etiquette, the author finds the phenomenon of dignity of these people. In her book, the Ukrainian elite of the XVII century emerges as a community of people that are positive, moderate, modest and mercantile in their own way, close to nature, with healthy instincts, with a sense of duty, entrepreneurial, hostess, devoted to family values, with a desire for beauty. Step by step, combining the mass of empirical material ("small" and marginal in terms of traditional historiography), the author creates a holistic image, conveys the taste of the era. It is not just detail; it is a purposeful feature. It is a work on entities and meanings.

Thus, T. Tairova-Yakovleva compensates for the outdated defect of Ukrainian historiography: the excessive politicization of the issue of the social face of the Cossack elders, the careless attribution of class selfishness, betrayal, pleasures, the fall of ideals. The small book by T. TairovaYakovleva elegantly and unobtrusively puts everything in its place. The Hetmanate appears before us as a living organism. It is not a chessboard for monarchs; it is a world where interesting, full-blooded people live, with healthy instincts and positive mentality.

\section{Child and childhood in the Hetmanate of the XVIII century: version of Igor Serdiuk ${ }^{12}$}

If in her book Tatiana Tayrova-Yakovleva fancies romantic optimism, then in the book of Igor Serdyuk another mood reigns. "Total patriarchal society" emerges here ${ }^{13}$, social "lower classes" ("commoners"), including

\footnotetext{
${ }^{11}$ Ibid. P. 50.

12 Сердюк I. Маленький дорослий: Дитина й дитинство в Гетьманщині XVIII ст. Київ: K.I.C. 2018. 456 c.

13 Ibid. P. 350.
} 
orphans, beggars, artisan students, homeless people, are at the forefront here. There are always an accident and death. It cannot be said that each of these two historians knows only one side of society. T. Tairova-Yakovleva, who deliberately remains within the XVII century, is the author of a series of thorough studies on the military-political tussle from Khmelnytsky to Mazepa with its endless intrigues, defeats, victims, instability, political impasse, betrayal, betrayal, frustration. The researcher knows well this "difficult" side of life of the early modern Ukrainian society, she obviously has felt the need to balance the picture from the inside. At the same time, Igor Serdiuk, seeking comprehensiveness in the characterization of the society of the XVII century, intuitively knowing about the "bright" side of life, is forced to untangle the gloomy private stories recorded in court cases, patiently seeking "reservations" about the full "normal" life.

The author's self-determination of Igor Serdiuk is a "new history", cultural and historical anthropology. It can also be noted that the organizing core of I. Serdiuk's book is the discourse of social history. This powerful systematic research claims to be complete. It is clear that this kind of research program cannot be limited to the use of only one method. The author uses a variety of research tools with all seriousness: mathematical statistics, microhistorical analysis, elements of psychoanalysis, many analytical analogies throughout Europe, and also (in this case it is the most important) the technique of everyday life. The presence of the latter is attested, first of all, by the author's actual actions, but also by the presence of formal markers in the form of characteristic references to the titles of the subdivisions of the book, such as "everyday practices", "children's space", "outsourcing", "ideas and practices".

I. Serdiuk's source base consists mainly of texts capable of generously supplying material for the studies of everyday life. These are the hetman's diaries and "autobiographical works of local origin", private correspondence, court cases.

The author points out: "In studies of the life of the common people of early modern Ukraine, the historian often has to go to sources, which is too attentive to casual cases"14. Court cases is gloomy material. Inevitably their gloomy shadow falls on the whole story of the historian. However, it is well worth it: "The litigation contains valuable clauses and details that sometimes do not relate to the case itself, but reflect elements of everyday life, the emotional sphere, the material culture". The author notes from the outset that "individual court cases have significant potential for anthropological reading" $" 15$.

\footnotetext{
${ }^{14}$ Ibid. P. 191.

${ }^{15}$ Ibid. P. 38-39.
} 
Igor Serdiuk's history of everyday life is like a "servant" of "social history"; it has no coherent and separate localization. However, it is clearly present along with other research technologies. It is dissolved throughout the text. The book mentions hundreds of names, draws dozens of situations, sorts out a number of cases. There are "stories" about a shepherd, a bastard, a widow, an influential and successful godfather, a family couple, a priestly clan at every step. It lists a number of "biographies" of mercenaries, artisans, students, childless families, heads of families. The heroes of the book are petty officers, commoners, clergy, beggars, dissenters.

For example, looking for the soil to determine the boundary between childhood and coming of age in the practices of the XVII century, Igor Serdyuk presents the "story" of the early marriage of the daughter of Nizhyn Colonel Vasily Kulakovsky, Evdokia. The circumstances of her life lead the author to the Shakespearean drama of private lives in the Ukrainian Hetmanate: "Juliette Capuletti and Evdokia Kulakovska were separated for two centuries, they belonged to different cultural spaces, and their stories demonstrate a change in public attitudes towards marriage at the unbrokenness of its legally allowed minimum limit» ${ }^{16}$.

The difficult history of the family from the Mrynske Village of the Kyiv Regiment begins with an epic introduction: "The drama happened on December $31 \ldots, 17$.

The "microhistorical analysis of the case of Roman Krasnoshchenko" covers 14 pages of the book (Pp. 374-387).

I. Serdiuk meticulously monitors the life practices of the investigated period: giving babies to "breastfeeding" mothers; contraception (or rather, its actual absence); overcoming infertility (including spellbinding); maternity infrastructure; baptism (baptized parents, institute of nepotism); "namepicking strategies" (every eighth boy in Poltava was Ivan, every eighth girl in Poltava was Mary); funeral ritual; swaddling clothes; childhood space (hut, stove, bench, dust, cradle, toys), "play practices"; search for fate outside the parental home.

A lot of shocking, extravagant, unique, unbelievable cases are presented in the book: birth of monstrosities and children with defects, accidents with children, infanticide, cases of refusal to bury the dead, the rite of chaining of the murderer to the dead body directly in the church, domestic beating and theft, arson. This kind of detailing may seem superfluous and unnecessary. However, it has a deep meaning: it is a cure for a simplistic view of historical reality.

\footnotetext{
${ }^{16}$ Ibid. C. 71.

${ }^{17}$ Ibid. C. 275.
} 
On the example of I. Serdiuk's book, one can trace such a feature of the studies of everyday life as a certain unpredictability of the cognitive action of the historian. Thus, in the section "Child in the Face of Death", the author has to describe the details of the funeral rites: church rules, practices of specific actors, burial place, money costs, force majeure. However, at the same time the author accompanies the description with such comments and remarks that at times it seems that the main characters of the section are clergy. The theme of infant mortality grows into another topic: the level of "professional capacity" of church ministers, the irony of fate, the borderline of the high with the banal. The details of the priestly life form an exotic spin where the earthly and the sacred intertwine intricately (singing of the dead next to harvesting hay or chopping firewood, church duty with money). Thus, the actual result (the priest's fate) competes with the declared plot (society's attitude to the child). There is the conclusion: "Disciplining of the church in the territory of the Hetmanate was slow and difficult ..."18. The author summarizes this phenomenon of contemporary history as follows: "This edition is more about adults than children"19.

By gathering a variety of information, I. Serdiuk opposes previous historiographic practices that have sinned with one-sidedness, exaggeration and straightforwardness in the estimates of the early modern Ukrainian society. He points that "...weaknesses in logical constructs built on broad demographic generalizations or general-oriented religious precepts" ${ }^{\text {20 }}$. There are:

1. Fantastic perceptions of the multiplicity in the XVII century, stereotypical perceptions of the fatalistic "callousness" of parents and almost indifference about the death of children.

2. The myth of the incredible size of the family: "The typical family in the Hetmanate, except for mother and father, consisted of 2-3 children under 14 years, not $5-10$ as stereotypes and ethnographic intelligence suggest" 21 .

3. The anachronism in the depiction of the education system of the time: "The word "pedagogy" ... is too artificial for the realities of the Hetmanate" 22.

4. Idyllic perceptions about the nature of interpersonal relationships: "Contrary to the numerous dissertations in the history of pedagogy, sources indicate the prevalence of "stick education" ... It must be remembered that physical violence in traditional society played an important role in building and maintaining hierarchical structures" ${ }^{\text {23 }}$.

\footnotetext{
${ }^{18}$ Ibid. P. 237.

${ }^{19}$ Ibid. P. 388.

${ }^{20}$ Ibid. P. 260.

${ }^{21}$ Ibid. P. 389.

${ }^{22}$ Ibid. P. 298.

${ }^{23}$ Ibid. P. 331
} 
Through the painstaking analysis of the infinite number of situations related to industrial activity, work, wages, etc., the author draws significant conclusions that characterize the early modern Ukrainian society: "the Hetmanate society was very young"; "children of the common people were not too attached to property and family..."; "a significant proportion of children in the Hetmanate region grew up and worked outside the family"; "staying with other people's families was a common thing"; "people of that time hardly thought that they were living by the harsh laws"24"

\section{Roman Lubavsky: "life practices, strategies and tactics of behaviour" in interwar Kharkiv ${ }^{25}$}

Roman Lubavsky's monograph is a consistent and expressive case of everyday life techniques. The author brings the category of everyday life to the title of his book. He specifically formulates a number of remarks about the methodological features of this modern technology, as well as he really writes the everyday life of industrial Kharkiv in the 1920-30s. Finally, R. Lyubavsky is aware of the right thing to do; he notes that often historians merely imitate "a new methodology for the Ukrainian community of historians"26.

The intrigue is that, at the beginning of his monograph, R. Lyubavsky announces the concept of the then Communist Party's power to form a "new person": "new ideals and norms", "education", "Sovietization", "utopianism", etc. But then, from section to section, the author actually states the collapse of this policy. This objection is especially convincing when there are purely micro-historical plots.

The subjects and provisions of R. Lyubavsky's monograph are taken from the microhistorical documentary routine. The author patiently searches for fragments of information in modest and unimaginable marginal sources: these are the minutes of meetings of commissions for establishing the living conditions of workers; lists of applicants for housing by trade union committees; minutes of meetings of factory committees; materials of surveys of the sanitary and technical condition of enterprises; correspondence of labour protection departments with central government agencies; applications and letters from workers to local authorities; acts of inspection of barracks, canteens, premises by inspectors of various structures; survey materials of workers' clubs; letters to newspapers; memories of Kharkiv's citizens.

R. Lubavsky consciously and systematically uses the concepts and categories characteristic of technology of everyday life: "lifestyle", "mode of life", "consumption practices", "body techniques".

\footnotetext{
${ }^{24}$ Ibid. P. 78, 306, 371, 387.

25 Любавський Р. Повсякденне життя робітників Харкова в 1920-ті - на початку 1930-х років. Харків: Раритети України, 2016. 226 с.

${ }^{26}$ Ibid. P. 22.
} 
The campaign "new power" as "housing redistribution" is the first under the scalpel of the studies of everyday life. Firstly, the ambitious programmatic documents of the Bolsheviks of 1918-1920 about "living standards of workers" have been cited. However, in the 1920s, Kharkiv's workers did not hurry to settle in the "bourgeois" quarters of the city, because they were afraid to fall into this category of "Bolshevik activists". Where macrohistorical discourse can only ascertain the very fact of the deployment of an equalization campaign, the microhistory is not content with merely analysing "general" government regulations and reports and dives into the routine of local traveling documentation; it finds out that everything was not so simple and straightforward: workers were in no hurry to "be happy"! Next: the author comes to the understanding that out-of-town migrant workers felt uncomfortable in the city's central neighbourhoods. It turns out that Kharkiv's workers remained conservatives in the housing issue, they got used to the closest to nature, land. In addition, the "bourgeois" premises were expensive to operate and far from the factory buildings. There is an extremely important clarification to the overall political picture: "Workers used more concrete life experiences than abstract political appeals to the authorities"27. Reading through the stacks of routine testimonies, the historian testifies that it was beyond the power of his predecessors, namely: the gap between the working mass and the party that seized power in the country on behalf of that mass. What macro-history argues at best as a common assumption, the studies of everyday life shows convincingly and irrefutably: the Bolshevik power was superficial and usurper.

In the same style, by similar means, the author estimates the results of mass housing construction that began in the late 1920s: "the lifestyle of the inhabitants of these settlements can be described as partially autonomous"; "this mode of life was familiar, traditional for the working population of the city"; new working-class settlements "formed enclaves in the city with their traditions and inner world"; "residents of individual homes were left out of the Soviet project of restructuring of life"; "human relations between neighbours often hindered the implementation of Bolshevik class politics"28.

The new stage of housing construction, which began in the late 1920's, was presented by the authorities as something unique: "city-gardens", "commune-cities", "New Kharkiv", etc. Instead, by the means of everyday history, R. Lubavsky disrupts the mask of social utopia and brings to light the divine earthly circumstances: "turn to shelter"; such surprising unexpected forms as the leasing of state-owned housing to leasehold of NEPmen (businesspeople in the early Soviet Union); "self-compacting" for the sake of

\footnotetext{
${ }^{27}$ ibid. P. 41.

${ }^{28}$ Ibid. P. 49, 55, 56.
} 
renting out part of your living space; reluctance of the Soviet nomenclature (superiors) to live in commune houses. Thus: “...the workers were guided by the principles of economic benefit, vital rationality, not the sense of class solidarity that power sought to instil in them"; (P. 52) "the workers did not live up to the expectations of the Bolsheviks; they adapted to carry out "old" daily practices within the new living space" ${ }^{, 29}$ (P. 66).

R. Lyubavsky found out that the idea of radical restructuring of the working life turned out to be unrealistic and not least because it was carried out on a residual principle.

Turning to the industrial sphere of working life, R. Lyubavsky is not limited to data on the growth of the number of enterprises and the number of workers on them, as to the saturation of production with new (mostly imported) machinery. He seeks "a study of the real state of affairs" ${ }^{\text {"30. This real }}$ state is revealed precisely through the "inside" and "upside-down" look. The author draws attention to the shops swamped with manufactured products and the remnants of production materials, to the extreme congestion and accumulation of the shops with production equipment, crowding, excessive concentration of dust and harmful gases, poor ventilation, poor lighting of shops, lack of utility spaces, and, as a result, increased injuries.

These facts, actually, are well known and can be found in "standard" documents. However, these facts can be seen as "shortcomings" (and, if desired, as "temporary shortcomings"). There are the microhistorical subjects involved, and it becomes clear the fundamental impossibility of the "forcible satisfaction" of workers and the "assault" modernization of production. It turned out that the rules of industrial hygiene and safety were deliberately violated by the workers themselves. The equipment was set up in such an incomprehensibly logical way that under certain circumstances the workers themselves turned off the ventilation equipment because it prevented them from working: founders did not hear the instructions of the master during the smelting of the metal. In another situation, workers clogged the ventilation pipe with garbage because it arranged wild drafts ${ }^{31}$.

The fact that many of the workers and the engineering intelligentsia had disdain for udarniks (shock workers), Stakhanovite workers and other "best" people in the production for appearances, collusion with superiors, privileges, was demonstrable.

A number of similar verdicts confirmed that during the Stalin industrialization the working conditions at the enterprises significantly worsened, the aural, storming rhythm of labour was established.

\footnotetext{
${ }^{29}$ Ibid. P. 52, 66.

${ }^{30}$ Ibid. P. 171.

${ }^{31}$ Ibid. P. 84.
} 
The studies of everyday life makes it possible to clearly emphasize in another story from the history of "socialist construction": unification and standardization of nutrition.

Within the traditional methods of historical writing it can be quite simply shown that the authorities were forced to abandon their ambitious plans, to correct them, to solve problems of life and culture on a residual principle. In particular, there was a backlog in the implementation of food plans. According to the government documents, in 1930, from the planned 37 kitchen factories across the Ukrainian SSR, only 9 were built. Only the studies of everyday life is able to put a real price on those nine kitchen factories that allegedly worked for the cause of socialism! Only microhistoric technology can show what these nine meant. These were not the kitchen factories that were able to build a "new" life. These were not the centres of the socialist dream. They were dominated by dirt, theft, unsanitary practices and rudeness. Employees of "advanced" food establishments avoided using expensive special machinery (automatic bread slicers, potato peelers, etc.), it rusted and failed. And where it did not become damaged, it was "helped" to break: "staff at food establishments perceived imported household machines as their worst enemies and did their best to disable them as they restricted the ability to speculate on food items" ${ }^{\prime 2}$. Moreover, next to the claim to build a "new society" there was a banal patriarchal hierarchy. One of Kharkiv's exemplary kitchens at a large "advanced" enterprise had a separate floor to serve the enterprise's engineering staff: here, the overalls of the service personnel were cleaner, the behaviour was more polite and the food was more caloric $^{33}$. This is a separate fact, but it is no accident. This is a fact-sentence. One such fact is enough to overwhelm the whole system of propaganda noise.

It's not just about the amount of food. The historian of the studies of everyday life attaches no less importance to the mental aspect - the state of human dignity. "Queues, commodity deficits have become one of the characteristic features of the everyday life of Kharkiv's workers in the 1920s and 1930s of the XX century, the sign of Soviet reality in the following decades", the author writes ${ }^{34}$. This is not a new position for our literature over the last two decades. However, R. Lyubavsky has been able to make additional arguments in support of this important provision and has every right to repeat it.

It is one thing to have statistics on consumption rates, size and filling of food rations and more and it is the other thing, when the "human" detail

\footnotetext{
${ }^{32}$ Ibid. P. 135.

${ }^{33}$ Ibid. P. 127.

${ }^{34}$ Ibid. P. 172.
} 
immeasurably shows the "real state of affairs": when foreign specialists received products in the privileged store of the "Insnab" system, they felt such glowing views of the Kharkiv's people that it seemed to them that they had stolen these products. Many of the foreign specialists were so dissatisfied with working and living conditions that they broke contracts and returned home early. The authorities tried to prevent their departure by every means possible: from endless promises to improve working conditions and accommodation to refusing to return passports ${ }^{35}$.

Using similar explanatory means, R. Lyubavsky demonstrates the underdevelopment of infrastructure and public utilities of Kharkiv, unsatisfactory state of urban transport, primitive level of cultural and educational work among workers.

Following the usual way, we can operate "systematic" data and repeat the information accumulated by the authorities themselves: cultural workers in working clubs lacked professional training and adequate knowledge, etc. However, we can use the look "from the inside": singers used church singing techniques to perform "revolutionary" songs at competitions of choral amateur groups; "being in the club's Soviet space, they used the practices they borrowed from the old functional space (the church) and used them in new contexts (singing revolutionary songs)"36. Similarly, there were examples of testimony that boredom was prevalent in working clubs, as well as the talk of Kharkiv's people that aesthetics in the church were higher than in the club.

"In everyday life, workers were guided more by rationality in life than political slogans," sums up R. Lyubavsky ${ }^{37}$. It is a sentence to the system, a sentence to the Communist Party.

\section{The mystery of the Stalin's sphinx: the project of Serhy Yekelchyk ${ }^{38}$}

The title of the original (English) edition of the monograph by Serhy Yekelchyk ${ }^{39}$ conveys the meaning of this project more accurately. The author concentrates and consistently prepares only one section - ideological, and anatomizes only the mechanism of contact between the authorities and citizens of the capital of Ukraine.

The first, but not the most essential, feature of the use of the tools of the studies of everyday life is the use of the iconic categories inherent in this

\footnotetext{
${ }^{35}$ Ibid. Pp. $129-130$.

${ }^{36}$ Ibid. P. 142.

${ }^{37}$ Ibid. P. 172.

${ }^{38}$ Єкельчик С. Повсякденний сталінізм: Київ та кияни після Великої війни. Київ: Laurus, 2018. $306 \mathrm{c}$.

39 Yekelchyk, Serhy. Stalin's Citizens: Everyday Politics in the Wake of Total War. Oxford: Oxford University Press, 2014.
} 
particular historiographic trend: "analysis of Soviet citizenship through the lens of daily practices", "Soviet identity", "daily political life" and "combination of political and personal in everyday life", etc.

A prominent feature of the author's style and a sign of the use of the technique of microhistory is that each section of his book Serhy Yekelchyk begins with a "story": case, incident, situation, mise-en-scene. This further emphasizes the author's willingness for narrative, for an interested consideration of human destinies and, ultimately, for the fate of the people. For example, the author describes an endless series of cases from the life of the first post-war months (in particular, a grisly picture of the public execution of German soldiers and police commanders $-200,000$ spectators watched it on Khreshchatyk!) and at the same time organizes them, finds a common denominator: "the concept of hatred" 40 .

On the example of the book by Serhy Yekelchyk, one can see and understand how laborious the cognitive approach is, which is called the studies of everyday life. There are hundreds and hundreds of statements, testimonies (at least listened to by the secret services of the secret services), spontaneous dialogues, inscriptions (for example, made by voters on ballots before being thrown into the ballot box). There is endless quotation of newspaper material, speeches and speeches by the functionaries. There are slow calculations: how many people passed Khreschatyk during one or the other parade, how many portraits of Stalin, Molotov, Khrushchev, Lenin were carried (individually!), how many "negative" votes for which candidate from Stalin to some local functionary - were thrown into ballot boxes. Hundreds of names of citizens who "lit up" in one or another situation were mentioned: they were exposed in anti-Soviet or simply negligent, put forward with an initiative, set themselves in the right place at the right time, exhibited as beacons, as a model for others; all these people were not famous, completely unknown for the reader, the peripheral, not even the second, but some seventh plan, pensioners, Stakhanovite workers, agitators, motherheroines, spontaneous boozers, military men, priests, factory administration, builders. The book is densely populated and certified with all these people. Finally, there are dozens of personal stories of Kyiv's residents with their troubles, demands, naive hopes, fears, sacrifice, scepticism.

Nevertheless, the endless stream of empiricism, and the narrative style of presentation is not purely rhetorical. They are strictly subordinated to one cognitive goal: to analyse the mechanism of formation and realization of citizens' loyalty to the regime, to solve the problem of "touch" of the masses to the power. This is a deep conversation about significant processes.

\footnotetext{
${ }^{40}$ Єкельчик С. Повсякденний сталінізм: Київ та кияни після Великої війни. С. 21.
} 
In this book the refrain repeats the theoretical organizing research findings: "the symbolic unity of the state and the people"; "it was a world of political illusion, in which one side seemed to study and the other to control the process"; "agitators became intermediaries between the authorities and the population"; "the population sometimes played along with the leadership"; "agitators ... knowingly or unknowingly bestowed a human face on Stalinism"; "Soviet elections were a ritual display of loyalty"; "participation in such events was not about a holistic set of Stalinist views, but about understanding the rules of daily political life and a willingness to adhere to them"; "in fact, Stalin's officials were fortunate that the behaviour of good citizens had little to do with internal beliefs" research, this is a full-scale historical study.

The author does not allow all the involved empiricism to flow. His technique is a "rich description" technique (by Clifford Geertz). He comments and explains all the actions of his characters: gestures, phraseology, slang, intonations, facial expressions, entourage, interiors (such as polling stations with home furniture and houseplants). He accompanies these descriptions with catchphrases and ironic remarks.

Organizing categories in transforming the empirical array into a complex explanatory system in S. Yekelchyk's book are such favourite formulas as "political ritual", "practices", "life strategies". One of such system-forming "practices" is bidding with the authorities. Here S. Yekelchyk develops the idea of Stephen Kotkin outlined in his "Magnetic Mountain" ${ }^{42}$ : the masses pretended to accept the rules of the game proposed by the authorities and patiently and relentlessly used this game to achieve their goals: to ensure at least minimal living conditions.

Among the "life strategies", he describes: "mastering the art of Marxist phraseology and newspaper stamps"; desertion of workers from the largest industrial enterprises of Kyiv: they were not satisfied with the poor wages and food rations; elections as a springboard and a moment for bidding citizens with power: for pensions, registration, assistance to the needy, public transport, repair of residential buildings, electricity supply, cancellation of grocery cards and cheaper goods. The "protest inscriptions" on the ballot papers before the vote were, in the understanding of S. Yekelchyk, a way of reporting daily problems: "Give bread", "Down with hunger", etc. The historian reflects on the contradictory nature of social protest in the Soviet system, when rhetoric, and approval, and protest are flowed in the same

\footnotetext{
${ }^{41}$ Ibid. P. 79, 96, 170, 176, 191, 231, 234, 235.

${ }^{42}$ Kotkin, Stephen. Magnetic Mountain: Stalinism as a Civilization. Berkeley: University of California Press, 1995. Режим доступу: http://ark.cdlib.org/ark:/13030/ft909nb5q7/
} 
statements: "Long live the Soviet power! Down with Stalin!", "I want to live as an unemployed person in America"43.

Much of the author's comments, by which the author "saturates" his descriptions, are ironic: "voluntary-forced"; importation of products before the holiday on May 1 as a "bribe to the people from power"; queues before polling stations as an archetype ("for decades, deficits and rations have instilled in the population the habit of queuing up"); schools of political education as "a world of political illusions, in which one side pretends to learn and the other to control the process"; political action as a fair ("adults combined love for Stalin with shopping, booze and dancing, often in the same room where they had just solemnly waited for the right to vote"); "the festive crowd glorifies the Soviet achievements for new consumer opportunities"; workers "were more willing to show love to the leader in elections than in daily casualties in the workplace"; the election results of 1950 "outweighed the results of previous elections..." some ballots, the author's comment is: "One voter wrote a poem where he asked to invent a way that would allow Stalin to live another two hundred years. Unfortunately, the 65-year-old Bogomolets died the same year, and this medical problem remained unsolved. This did not prevent another unknown voter from breaking the record in the 1950 election and wishing (in Ukrainian) "a thousand years of life for Stalin's father!"45.

Also, S. Yekelchyk introduces statistics. However, these are not traditional production or population data, etc. These are "human" statistics: emotions, idiocy, paradoxes, various incredible things. For example, the letter-poem "The Word of Stalin from the Ukrainian People" written by sixteen most prominent Ukrainian poets. It turned out that this letter was signed by 9316973 citizens of Ukraine in September-October 1944, including 158272 from Kyiv (personally!) ${ }^{46}$.

The historian ironically reports on the number of portraits of each of the heads of state, which "testifies to the official hierarchy of rulers whose wise rule should be glorified by the workers": on May 1, 1949, the people of Kyiv carried: 799 portraits of Stalin, 583 portraits of the first deputy head of the Council of Ministers, 563 portraits of Khrushchev - the former first secretary of the Central Committee of the Communist Party and the patron of the republic in the Kremlin, and only 422 portraits of $\operatorname{Lenin}^{47}$. This is a sort of personality cult in the details.

\footnotetext{
${ }^{43}$ Єкельчик С. Повсякденний сталінізм: Київ та кияни після Великої війни. С. 99, 146, 223.

${ }^{44}$ Ibid. P. 70, 96, 153, 201, 211, 216-217.

${ }^{45}$ Ibid. P. 221.

${ }^{46}$ Ibid. P. 48.

${ }^{47}$ Ibid. P. 67.
} 
Our history, in the light of the studies of everyday life, appears in a completely different form. Let's take the moment that classical historiography knows about $99 \%$ of the voter turnout of the USSR citizens for the elections and even makes ironic remarks about it. However, Serhy Yekelchyk disassembles the technology of preparation and holding elections, in addition, by writing a detailed scenario of voter behaviour. Here we are no longer a superficial statement - 99, but a complete understanding of the atmosphere, and we understand that before (before this study) we have not understood the true weight of this implausible indicator. That is not even an indicator, but a semiotic key to understanding the essence of the regime. Having recreated a number of incredible (in terms of classical historiography) situations, the author restores the true price of these 99 . For example, the task was not only to get all $100 \%$ of the electorate to vote, but to get everyone to vote by $8 \mathrm{am}$ ! Indeed, there were long queues and jolts before the doors of polling stations at the moment of their opening. Some people had occupied this queue the night before! At polling stations, citizens went not only with dense flows, but mostly with flags, orchestras, flowers, portraits of leaders and leaders a picture that could be fully conveyed only by the means of microhistory.

Undoubtedly, the presentation of the elections to the authorities of 1946, 1947 and 1950, the unfolding of their dramaturgy are the best pages of Serhy Yekelchyk's book (section "Election Day", Pp. 193-232). Also, it is a demonstration of the techniques of everyday history.

In this section, the studies of everyday life is presented in all its uniqueness and cognitive effectiveness. The leading place here belongs to the casus, mise-en-scene, natural bursts, anomalous acts, strange things. It is clear (as the author himself writes) that passive forms, daily and standard, are statistically dominant. However, the historian is aware that "social phenomena are best explored by deviating from them". In addition, the spontaneous actions of real people (usually with names and realistic features) selected by the historian give the impression of authenticity, immediacy, they magnetize the reader's attention and imagination.

Here are the voters of one labour collective go to the polls by march, columns, with slogans and posters, portraits of leaders and government, with songs, in festive clothing, with flowers and greenery. Just before the polling stations open (at $6 \mathrm{am}$ !), there are short rallies at which the heads of election commissions greet voters with a holiday and invite them to fulfil their public duty. Here is the one member of the party that gets reprimanded for appearing at the polling station at 14:00 and being the last voter to vote at the 9th polling station of the Leninsky district of Kyiv in February 1947!

This is only the beginning. Further events develop according to the classic canons of drama - in an incremental manner. The contest for the right to go to 
the polling station is unfolding: "Being the first to cast a ballot in the ballot box at a metropolitan polling station was considered an extraordinary privilege and not only because the first voter could get to the pages of the morning newspaper... apparently, they thought that the one who votes first got higher status in their community"48. Everything was solved by the situation, the moment, the impromptu. Officials and newspaper rhetoric insisted that the "famous people and heroes", "the best citizens of Kyiv" veterans, Heroes of Socialist Labour, Stakhanovite workers, inventors, actors, mother-heroines - should have voted first. However, in some places the people's initiative won and the old-timers, the disabled people became lucky.

The Voting Atmosphere comes next. This is a "strictly regulated political space", "a space filled with posters, slogans and portraits of leaders". Election commission officials and campaigners watch every word and gesture of the voters and note what is happening. There are red brocade and silk. There are Soviet emblems on ballot boxes and booths. There are permanent pioneers that salute the flag. There is an idiocy of instructions: "Leave one candidate's name on the ballot for which you vote, strike out the other", but there is one and only one name in the ballot! Because of this, part of the voters simply did not know what to do and left ballots in the booth or asked for help from the polling station employees ${ }^{49}$.

Stalin himself kept a close eye on the voters - from numerous posters, portraits (sometimes full-grown) and plaster busts. One of the portraits was arranged in such a way that "it seemed as if those who threw the ballot in the ballot box brought a symbolic gift to Stalin".

The atmosphere of political annoyance is so affecting that the voters are subconsciously drawn into the tragedy: they are baptized before putting the ballot in the ballot box, saying "God, help our voters and the great Stalin", kissing the ballots before lowering them in the ballot box, kissing the portrait of Stalin (like an icon). Citizens used to make "patriotic inscriptions" on the ballot papers; there were thousands of them. Among them, there were the wishes to live for Stalin for another two hundred years, as well as "a thousand years of life for Stalin's father". The ballot papers thrown into the ballot box in agreement with the election of a designated nominee to the council of one or another level were credited with: "and for Comrade Stalin", "and for the Great Teacher Stalin", and "death to the English and American warmongers!", etc. ${ }^{50}$ Such actions are small cases in the middle of a routine, but they throw bright light on the whole system.

\footnotetext{
${ }^{48}$ Ibid. C. 199.

${ }^{49}$ Ibid. P. 205-206.

${ }^{50}$ Ibid. P. 206-221.
} 
After the election, there were celebrations and festivities with entertainments, a buffet, music, dances, free movie shows, performances of artists, professional orchestras, amateur choirs.

Serhy Yekelchyk also "forces" the procedure (action!) of vote count through a sieve of microhistorical analysis. Firstly, it turned out that the authorities did not know the exact number of voters. What was the turnout? In the 1946 elections, only 39 (!) voters were absent from the total number of 484 406. Thus, the turnout was $99.989884 \%$ ! - officially announced $99.99 \%$. After that, the historian draws out small manipulations, techniques by which he obtained a "smooth" picture of the consistent, year after year, growth of the "consciousness" of Soviet citizens. How can this increase be demonstrated from year to year? - "fine calculations were needed". There are the hundreds of percentages in the indicators of positive voting for the nominated candidates: $99.27 \%$ in Kiev (1946), 99.46\% (1947). Finally, in the 1950 elections to the Supreme Soviet of the USSR, $99.8 \%$ of voters voted in favour (1200 voted against, 5 ballots were rejected $)^{51}$.

Exotic statistics such as the number of votes against a particular candidate are also involved. Of course, then it was not made public. Thus, in the elections to the Verkhovna Rada of the USSR in February 1947, Stalin scored 0 votes against, Molotov -60 , Kaganovich -696 , the head of the Republic Khrushchev - 228, the first secretary of the Kyiv City Committee of the Communist Party of Ukraine Petro Matsui - 223, chief architect of the city Alexander Vlasov - 230, city mayor Fyodor Chebotarev - 360 votes "against" 52 .

In the end, using the tools of the studies of everyday life, Serhy Yekelchyk brings the reader to the understanding that the Stalin authorities, albeit so omnipotent, were in fact panic-stricken with their people, closely watching their moods and carefully extinguishing the slightest threats of mass dissatisfaction. Even a minor failure in the elections to the authorities caused a stir in the Party Committees, in the corridors of power. The power was maintained while the citizens remained "conscious".

The loyalty of Stalin's citizens was ritual, superficial, not backed up by certain political convictions, without an organic assimilation of Bolsheviks' ideology, pragmatic. In the days of late Stalinism, it was not about a holistic set of Stalinist views, but about understanding (required) rules of daily political life and their willingness to adhere to them.

After all, not only what the historian claims is important, but also how he does it. He substantiates his vision undeniably. He maximizes the power of

\footnotetext{
${ }^{51}$ Ibid. P. 216-217.

${ }^{52}$ Ibid. P. 217-218.
} 
the reader's attention. It creates a multidimensional image, a multifaceted model of historical reality, and ultimately leaves many other things in the reader's mind besides the "direct" provisions regarding the era when the "Stalin's citizens" lived.

\section{CONCLUSIONS}

Considering the works of four contemporary historians who specialize in the history of Ukraine from different periods, one can confidently point out a few fundamental points that identify the studies of everyday life as a new historiographical approach and warn against lightening the problem.

1. The studies of everyday life is not an "easy genre", it is not "historical journalism". It is not an escape from analytics. The studies of everyday life is the search for meaning, truth, understanding, as the other types of history. Apparently, within one work, it is easily combined with other technologies of historical knowledge: social history, psychohistory, intellectual history, different variants of cultural and historical anthropology.

2. There are a number of issues on which the studies of everyday life is more effective than classical historiography. These are thematic fields, such as the history of mentalities, the relationship of power and personality, the question of the survivability of certain regimes, the fate of certain doctrines and utopias. The essence is not only in the abstractions, but also in the details. The essence is in the details. There are such subjects and even topics that are different. It happens. And it must be accepted.

3. The studies of everyday life is convincing of a special type. Moreover, the daily historian is more convincing not by some incomprehensible way, but by immersing himself in the thick of empiricism, which historians have neglected for decades. Thanks to this, the historian gets access to the peripheral expanses of society, to the "nooks and crannies" of history, and can see what has been previously "in the shadows" and therefore disregarded. Traditional methods, for the most part, give a one-sided picture: whether or not it was; what were the quantitative parameters. The studies of everyday life shows everything stereoscopically and multifaceted, surrounded by human motives and emotions. Thus, the studies of everyday life usually handles small details, but these are special details. They have considerable probative power. In them, like in the drop of morning dew, the whole world is reflected.

4. The best sources of evidence for this kind of history are mass or at least serial sources: private diaries (which usually record the same series of events over time); private correspondence (especially between mature couples of correspondents: husband and wife, student and teacher); transcripts of party conferences; reporting of special services on the mood of the population; legal cases; acts of inspections of living conditions; collections. 
5. The history in general is a special kind of intellectual pursuits. Any kind of story requires from a historian: empathy, advanced imagination, curiosity, mastery of the word. However, the studies of everyday life seems to be particularly demanding in this context. Here, one can hardly count on success, focusing solely on formal prescriptions about how to "write" the story of everyday life, what categories to use or what ideologists to use. The secret of the success of historians who practice daily history is not in the grinding of objects of study, or in the observance of any special formal procedures. The secret lies in the talents of the historian, in his ingenuity, in his hard-working patience: the ability to shuffle through the mountains of routine documents in search of vivid testimony, candid confessions, shocking truths, power-laced expressions. They look for material for their generalizations not just in one or two archival funds, but literally everywhere. Therefore, the studies of everyday life requires considerable erudition from the historian.

\section{SUMMARY}

The article traces the boom of theoretical and methodological formal interest in the foundations of the studies of everyday life in Ukrainian historiography. It is argued that a significant problem remains the need to overcome such shortcomings as imitation of the studies of everyday life, frank biography, empirical routine, factual mischief. The article calls on "practicing historians" to work hard. The author sets the task: not historiosophy for historiosophy, but historiosophy for historiography.

On the example of the works of four contemporary historians specializing in the history of Ukraine of different periods, Natalia Tairova-Yakovleva, Igor Serdiuk, Roman Lyubavsky and Serhy Yekelchyk, the author shows that the studies of everyday life is an effective means of finding answers to the classic questions of historical science. The author tries to show the difference between traditional storytelling and the technology of everyday life, as well as to understand how this magic works when "from the smallest point" comes the essence. It is argued that the studies of everyday life is most effective in such thematic fields as the history of mentalities, the relationship of power and personality, the question of the survivability of certain regimes, the fate of certain doctrines and utopias.

\section{REFERENCES}

1. Нариси повсякденного життя радянської України в добу непу (1921-1928 рр.): Колективна монографія / Відп. ред. С.В. Кульчицький. В 2 ч. Київ: Інститут історії України НАН України. Ч. 1. 2009. 445 с.; Ч. 2. 2010. 382 c. 
2. Українське радянське суспільство $30-\mathrm{x}$ pp. XX ст.: нариси повсякденного життя. / Відп. ред. С. В. Кульчицький. Київ: Інститут історії України НАН України, 2012. 786 с.

3. Повоєнна Україна: нариси соціальної історії (друга половина 1940-х - середина 1950-х рр.). У 2-х книгах, 3-х частинах / Відп. ред. В. М. Даниленко. - Київ: Інститут історії України НАН України, 2010. $351 \mathrm{c}$.

4. Повсякдення ранньомодерної України. Історичні студії в 2-х томах. / Гол. ред. В. Смолій. Т. 1. Практики, казуси та девіації повсякдення Київ: Інститут історії України НАН України, 2012. 328 с.; Т. 2. Світ речей і повсякденних уявлень. Київ: Інститут історії України, 2013. 358 с.

5. Історія повсякденності: теорія та практика. Матеріали Всеукраїнської наукової конференції, Переяслав-Хмельницький, 14-15 травня 2010 p. Переяслав-Хмельницький, 2010. 246 с.

6. Історія радянської повсякденності: на перехресті джерел. Збірник матеріалів Всеукраїнського науково-теоретичного семінару, 14-15 травня 2015 р., м. Вінниця. Вінниця : ТОВ «Нілан-ЛТД», 2015. $156 \mathrm{c}$.

7. Рікер, Поль. Історія та істина. Київ: КМ Academia, Пульсари, 2001. $393 \mathrm{c}$.

8. Таїрова-Яковлева Т. Повсякдення, дозвілля і традиції козацької еліти Гетьманщини. Київ: ТОВ «Видавництво “КЛІО” 2017. 184 с.

9. Сердюк I. Маленький дорослий: Дитина й дитинство в Гетьманщині XVIII ст. Київ: К.І.С., 2018. 456 с.

10. Скельчик С. Повсякденний сталінізм: Київ та кияни після Великої війни. Київ: Laurus, 2018. 306 с.

11. Yekelchyk, Serhy. Stalin's Citizens: Everyday Politics in the Wake of Total War. Oxford: Oxford University Press, 2014.

12. Kotkin, Stephen. Magnetic Mountain: Stalinism as a Civilization. Berkeley: University of California Press, 1995. URL: http://ark.cdlib.org/ ark:/13030/ft909nb5q7/

Information about the author: Liakh S. R., Doctor of Historical Sciences, Professor, Head of the Chair of Ukrainian History, Zaporizhzhia National University 66, Zhukovsky str., Zaporizhzhia, 69600, Ukraine 